Copyright (C) 2021 by Cherkas Global University

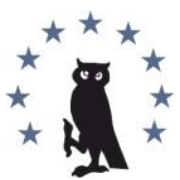

Published in the USA

Russkaya Starina

Has been issued since 2010.

E-ISSN: 2409-2118

2021. 12(2): 87-94

DOI: $10.13187 /$ rs.2021.2.87

https://rs.cherkasgu.press

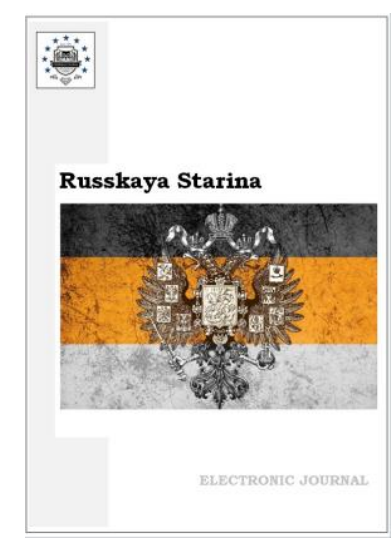

\title{
Life and Service to the Fatherland of General A.A. Karpov
}

\author{
Andrey V. Venkov a, * \\ a Federal Research Centre the Southern Scientific Centre of the Russian Academy of Sciences, \\ Russian Federation
}

\begin{abstract}
In Rostov region since 2013, the decision to rebury the remains of three Don Cossack generals, heroes of the War of 1812 - Lieutenant General A.A. Karpov, Major General P.M. Grekov and Major General G.A. Dyachkin is delayed. Their remains were found by students and teachers of the Cossack cadet corps named after Ya.P. Baklanov in Shakhty in Tarasovsky district of the Rostov region. During the revolution of 1917, their former graves were destroyed and looted. The bodies were found lying randomly mixed with construction debris. The process of identifying the remains is still underway. When it is completed, the Don generals will be interred according to their status and merits. This article gives a brief biography of one of the honored Don generals, whose ashes have not yet found rest. Studying his life path, we found a number of problems connected with the formation of a new Don Cossack elite, which began to form in the late 18th - early 19th centuries.

Keywords: Cossacks, service, Cossack elite, wars, Don artillery.

\section{1. Введение}

В казачьем движении в Ростовской области есть одна не разрешенная до конца проблема. В 2013 г. в слободе Дячкино Тарасовского района Ростовской области стараниями учащихся и преподавателей Шахтинского Я.П. Бакланова казачьего кадетского корпуса были обнаружены захоронения трех донских казачьих генералов, героев войны 1812 г. генерал-лейтенанта А.А. Карпова, генерал-майора П.М. Грекова и генерал-майора Г.А. Дячкина. Их прежние захоронения были разорены во время революции. До сих пор не разрешен вопрос о месте перезахоронения найденных останков. Есть предложения захоронить их там же, где они обнаружены, либо в цокольном помещении Новочеркасского патриаршего всеказачьего собора, либо по месту рождения двоих из них - в станице Старочеркасской. Уже несколько лет идет процесс идентификации останков. Когда он завершится, донские генералы будут преданы земле согласно их заслугам. Предлагаемая статья дает краткую биографию одного из этих несправедливо забытых героев, который входил в военную элиту Войска Донского в XIX в., был создателем донской артиллерии, а на Бородинском поле командовал казачьими войсками на левом фланге.
\end{abstract}

\section{2. Материалы и методы}

Представители донской казачьей верхушки стали объектом изучения еще в начале XX в. (Донцы XIX века, 1907), тогда же были составлены краткие биографии казачьих

\footnotetext{
${ }^{*}$ Corresponding author

E-mail addresses: andrey_venk@rambler.ru (A.V.Venkov)
} 
генералов и офицеров, заслуживших орден Святого Георгия (Донцы-кавалеры, 1911). Признанным специалистом по истории донской казачьей элиты, получившей статус российского дворянства, был Н.С. Коршиков (Коршиков, 1999). О боевом пути донских генералов в 1812 г. есть интересное исследование В.М. Безотосного (Безотосный, 1999). Большой материал о жизни героя нашего исследования собрал С.В. Корягин (Корягин, 1999). Важнейшим источником по основным этапам жизни донской служилой верхушки являются послужные списки, хранящиеся в Государственном архиве Ростовской области и Российском государственном военно-историческом архиве.

При написании статьи автор опирался на принцип историзма и использовал антропологический подход, поскольку исследовал биографию представителя особого сообщества; применялся просопографический анализ: прослежены жизнь и служба одного из выдающихся донских генералов со второй половины XVIII в. до первой половины XIX в.

\section{3. Обсуждение и результаты}

Донская верхушка - старшина - сложилась еще в XVII в. Однако борьба за власть внутри Войска Донского, борьба с центральной российской властью за сохранение или даже расширение казачьей автономии и казачьих привилегий влияли на ее состав. Наш герой являет собой образец представителя новой донской казачьей верхушки, которая стала складываться в конце XVIII в. и окончательно оформилась уже в начале XIX в. в несколько ином статусе.

Когда наш герой, Аким Акимович Карпов, по-настоящему начал службу, в донской старшине, официальной элите Войска, числилось 47 человек. Это были бывшие атаманы и наиболее отличившиеся командиры казачьих полков.

Среди донской старшины значились пятеро Денисовых, четверо Грековых, трое Иловайских, двое Кутейниковых, двое Ребриковых, двое Агеевых, по одному представителю прочих родов. Главнейшим из старшин считался атаман Алексей Иловайский, за ним по списку и по старшинству - Себряков Михаил, далее двое Денисовых, потом войсковые судьи Мартынов и Луковкин, поднимаемые вверх за верность престолу. Большая часть потомственные старшины. Некоторые получили «старшинство», как только в службу вступили: таковы Себряков, Григорий и Кондрат Денисовы, Алексей Пушкарев, Иван Дячкин, Алексей Краснощеков. Последний стал донским старшиной в 11-летнем возрасте, «по заслугам отцов».

Но были среди донской старшины и простые «казачьи дети», пробившиеся вверх, благодаря личным заслугам. Таков Луковкин, отличившийся против Пугачева и удачно женившийся, выкрест из чеченцев Осип Данилов, старший из Грековых - Макар, и еще один Греков - Василий, отец нашего героя Аким Карпов, оба Агеевы, Петр Кубанов; среди них же - отец будущего атамана - Иван Федорович Платов (Венков, 2013: 30-31).

Описываемый нами Аким Акимович Карпов родился примерно в 1764 г. В послужном списке за 1799 г. он указал свой возраст - 35 лет (ГАРО. Ф. 341. Оп. 1. Д. 208. Л. 85 об.). В послужном списке за 1800 г. - 36 лет (ГАРО. Ф. 341. Оп. 1. Д. 231. Л. 43 об.). Изначально он числился казаком города Черкасска (Донцы XIX века, 1907: 170).

Родословная нашего героя небогата. Отец вышел в старшины в 1764 г. при атамане Степане Ефремове. Умер он в 1787 г. и записан как Аким Карпович (Корягин, 1999: 6). То есть «Карпов» - отчество отца нашего героя. Родовое прозвище неизвестно и позже нигде не всплывает. И наш герой, Аким Акимович получает фамилию «по деду» - Карпов. Напомним, что, уезжая с посольством в Европу, царь Петр І записался как Петр Алексеевич Михайлов - по деду Михаилу Федоровичу. Так что подобное образование фамилий на Руси было делом обычным.

Аким Акимович имел младшего брата, Ивана Акимовича, и двух сестер, Евдокию и Екатерину.

Казаком на службу он был записан 10 мая 1778 г., в 14 лет, и целых 4 года просто числился на службе.

В 1782 г. М.И. Платов, собирая полк в Чечню, зауряд-есаулами (впоследствии произведенными Канцелярией в есаулы) взял Акима Карпова и Василия Герцова, которым было по 17-18 лет. Герцов был сыном таможенного чиновника, и Платов, видимо, рассчитывал на капиталы его отца в случае денежных затруднений в полку. Выбор Акима 
Карпова, возможно, объясняется тем, что шурин Платова был женат на сестре нашего героя, или тем, что отец Карпова и отец Платова были старшинами «из казачьих детей» и поддерживали друг друга.

Впрочем, детям таких старшин, получившим прекрасные возможности карьерного старта, приходилось служить по-настоящему. И наш герой записал в послужном списке: «782-й, 783-й и 784-й на Кавказской линии у содержания передовых постов и разъездов и пограничной стражи, где между тем неоднократно был в экспедициях за Кубаном, на Лабе и в Чечне и имел с тамошними народами неоднократные сражения» (ГАРО. Ф. 341. Оп. 1. Д. 208. Л. 867). Полк Платова участвовал в экспедиции П.С. Потемкина в Чечню: «и битвы гремели на берегах Валерика, Гойты, Рошны и Гехи... Чеченцы на время присмирели», писал В. Потто (Потто, 1994: 128-129). Затем Аким Карпов участвовал в боях на Кубани и записал: «785-й во всеобщем Войска Донского на Кубань поголовном походе и того же года в отрядном походе так же для пресечения набегов тамошних народов» (ГАРО. Ф. 341. Оп. 1. Д. 208. Л. 86).

Отслужив на Кавказе, Аким Карпов в полку полковника К.К. Сулина 1 мая 1786 г. отправился на службу в недавно приобретенную Таврию. В послужном списке записано: «786-го, 787-го и 788-го в Таврической области для содержания по берегам Черного моря кордонов и разъездов, а также был в экспедиции в Тамани с нынешним генералом от кавалерии и кавалером графом Денисовым» (ГАРО. Ф. 341. Оп. 1. Д. 208. Л. 86). За время службы в Таврии Аким Карпов получил чин армейского поручика (27 марта 1787 г.) (ГАРО. Ф. 341. Оп. 1. Д. 208. Л. 85 об.).

Здесь же его застало начало войны с Турцией. Но с турками наш герой не воевал. С 1 января 1789 г. он назначен войсковым есаулом. Обычно войсковые есаулы выбирались на Войсковом Круге по два на Войско и исполняли функции помощников при атамане, позже, в XIX в., они исполняли обязанности адъютантов при войсковом наказном атамане. На этой должности Аким Карпов находился два года, 1789 и 1790. К этому времени относится и его женитьба.

Женился наш герой на штаб-офицерской дочери Марфе Васильевой, в девичестве Иловайской, на племяннице войскового атамана. Она родила ему 8 детей и материально, видимо, не бедствовала. Но в послужном списке за 1799 г., через 10 лет после женитьбы, у Акима Карпова записано: «крестьян и подданных не имеет» (ГАРО. Ф. 341. Оп. 1. Д. 208. Л. 85 об.). Получается, что он пошел «в зятья» к брату войскового атамана Василию Ивановичу Иловайскому.

Вообще брачные отношения всей родни Акима Карпова подпадают под характеристику «династические браки». Сестра Евдокия вышла за сына опального донского атамана Данилу Степановича Ефремова, брат Иван женился на дочери наказного атамана Василия Машлыкина, младшая сестра Екатерина вышла за Григория Дячкина, старшинского сына и будущего генерал-майора.

1 января 1791 г., отслужив войсковым есаулом и женившись, Аким Карпов становится войсковым старшиной, получает право командовать полком. 1 марта 1791 г. с полком Дмитрия Иловайского, родного дяди жены, он отправляется в Белоруссию и там, вместо старшего родственника, с 1 марта по 27 ноября командует полком «у содержания по реке Двине кордонов» (ГАРО. Ф. 341. Оп. 1. Д. 208. Л. 86). Наконец, 1 октября 1792 г. Аким Карпов получает в командование полк «своего имени». В Белоруссии и на Украине в это время стоят лучшие казачьи полки, и ситуация должна закончиться Вторым разделом Польши, но наш герой «с вверенным донским казачьим полком» отправляется на Кавказ. Там он около четырех лет (до 1 августа 1795 г.) служит «на Кавказской линии у содержания передовых постов и разъездов» (ГАРО. Ф. 341. Оп. 1. Д. 208. Л. 86). Полк его стоит на Кубани, и Аким Карпов участвует «в неоднократных с кубанскими народами сражениях» (Корягин, 1999: 6).

Его младший брат, Иван Акимович, за это время обогнал Акима Акимовича в чинах, отличившись в кампании 1794 г. в Польше. Там в августе 1794 г. полки И.А. Карпова и B.M. Серебрякова «получили повеление переправиться через Вислу прямо на неприятельские батареи. Казаки сняли с себя мундиры, седла с лошадей и с одними дротиками в руках, с военными кликами, вылетели из лесу и ринулись в Вислу. Поляки так оробели от сего, что оставили все пункты и бежали» (Записки донского атамана, 200о: 71-72). За этот подвиг Иван Карпов был произведен в премьер-майоры. 
Родственные связи и административные способности помогают Акиму Карпову избавиться от нудной пограничной службы в глухомани. В 1796 г. он назначается начальником в Медведицком сыскном начальстве. Здесь он получает майорский чин, и на следующий год, 10 ноября 1797 г., ему поручают организовать донскую артиллерию. На Дону своя войсковая артиллерия была, она участвовала во всеобщем походе казаков на Кубань, когда последний раз воевали с турками. Теперь ее доводили до штатов русской армейской конной артиллерии (Преснухин, 2011: 19).

19 февраля 1798 г. новый донской атаман В.П. Орлов доложил императору Павлу Петровичу о сформировании первой конной артиллерийской 12-орудийной роты. Вторую роту готовили дольше. В это время готовилось выступление 22 донских полков к западной границе на случай войны с Францией. 15 мая 1798 г., в день выступления, Орлов доложил о готовности и второй роты. Однако приказа о выступлении в поход донской артиллерии не было. О ней вспомнили, когда части русской армии уже собрались на границе. С 1 сентября 1798 г. Аким Карпов с конноартиллерийскими ротами выступил в поход и до конца 1799 г. находился с ними в г. Пинске.

Во время похода, 17 сентября 1798 г., он был произведен в подполковники и уже в Пинске 2 ноября 1799 г. получил чин полковника.

Как известно, отношение Павла I к союзникам России изменилось, и он послал Войско Донское через Оренбургские степи в поход на Индию, поход этот прервался в 1801 г. со смертью императора. И Аким Карпов с 30 января по 5 мая 1801 г. вместе с донской артиллерией находился в походе «к стороне Оренбурга» (ГАРО. Ф. 344. Оп. 1. Д. 71. Л. 38).

Вступление в атаманскую должность М.И. Платова ознаменовалось началом эпопеи с перенесением донской столицы г. Черкасска на другое место. Но сначала заливаемую в половодье водой столицу стали укреплять насыпью. Для этого создали два «рабочих полка», которые прибыли на службу на телегах и стали возить землю для насыпи (Венков, 2014: 221). Жители донской столицы, некогда заявлявшие в переписке с Москвой: «Нам потная работа не в обычай», - презрительно называли эти полки «кучурами» (искаженное «кучер»). Даже поговорка появилась: «Не мой там ноги, там поганый кучур воду пил». И столичный житель, полковник Аким Карпов, был поставлен командиром такого полка, о чем свидетельствует его послужной список: «Ныне находится сего 1802 июня с 13-го со вверенным казачьим полком для высыпки города Черкасска» (ГАРО. Ф. 344. Оп. 1. Д. 71. Л. 37 об.-38).

Но все же в том же году его вернули на пост командира донской артиллерии, и 21 сентября 1802 г. и 21 сентября 1803 г. он удостаивается Высочайшего благоволения «за исправность артиллерийских рот», а в 1804 г. с 1-й артиллерийской ротой участвует в экспедиции «за Кубаном», и, «командуя в корпусе авангардом, с тамошними горскими народами был в сражениях». В декабре 1804 - январе 1805 г. бои шли на Большом Зеленчуке, на Урупе, на Лабе, на Малом Зеленчуке, за которые 7 марта 1805 г. Аким Карпов был пожалован орденом Святой Анны 3 класса. Тогда же, в марте 1805 г., он участвовал в экспедиции в Кабарду, которую, как считал Аким Карпов, вернули в «подданство России» (ГАРО. Ф. 344. Оп. 1. Д. 226. Л. 5 об.-6).

С 21 сентября 1805 г. по 12 ноября 1806 г. Аким Карпов с 1-й ротой числится в Днестровской армии, Затем «с того числа в Молдавской армии и был с ней в неоднократных с неприятелем сражениях» (ГАРО. Ф. 344. Оп. 1. Д. 226. Л. 6 об.). Речь идет о русско-турецкой войне 1806-1812 гг., которую Аким Карпов начал в составе 11-й дивизии генерала М.А. Милорадовича. Трудно перечислить все сражения, в которых наш герой участвовал. Мы опишем лишь один эпизод, когда он в составе отряда донского генерала И. Исаева 1-го был послан за Дунай на соединение с сербскими войсками. Под Видином разгорелся бой с Мулла-пашой. Турки засели в трех окопах, сербское наступление было отбито, тогда Исаев атаковал с батальоном Олонецкого полка, казаками, арнаутами и пандурами. Все три окопа были взяты, захвачены 4 пушки и 13 знамен. Раненный Муллапаша заперся в Видине.

В послужных списках донских артиллеристов, бывших в отряде Исаева 1-го это событие проходит вообще как сплошной пятидневный бой: 18 июня - при селениях Малайнице и Неготине, 19 июня - при взятии штурмом неприятельских укреплений, бывших на Дунае, 19-22 июня - при взятии штурмом укреплений у селения Малайницы, на р. Штубик. 
Победа была громкая, но и наградили казаков щедро. Генерал-майор Исаев 1-й получил алмазы к Ордену Святой Анны 1-й степени. Капитан А.И. Исаев 4-й был награжден чином майора и Орденом Святого Георгия 4-й степени («с охотниками казаками ходил на штурм, отбил 1 мортиру, 1 пушку и взял 2 знамени»). Так же Георгия 4-й степени получил 1-й Донской артиллерийской роты полковник А.А. Карпов 2-й (Корягин, 2014: 37).

Эта война с турками оказалась самой продолжительной. Весь 1808 г. тянулось перемирие. Зато в 1809 г. Аким Карпов был награжден орденом Святой Анны 2-й степени (за бои под Браиловым и Гирсово), золотой саблей с надписью «За храбрость» (за взятие крепости Кюстенджи) и произведен в генерал-майоры (за сражение под Росевато). Затем были блокада Силистрии и сражение у Татарицы. Но войну закончить не удалось. Еще полтора года Аким Карпов дрался на турецком фронте, вновь осаждал Силистрию, сражался под Шумлою, брал Рущук и Никополь. Так и не дождавшись окончания войны, в сентябре 1811 г. он был переведен в Гродненскую губернию, где во главе казачьего полка должен был содержать пограничные кордоны.

1 марта 1812 г. Аким Карпов был назначен командовать всеми казаками 2-й Западной армии П.И. Багратиона. Под его началом оказалось сразу 8 казачьих полков. Таким же корпусом в 1-й Западной армии командовал М.И. Платов.

В своем послужном списке за 1816 г. Аким Карпов начинает описание войны 1812 г. так: «18 июня выступили от границы из Бреста Литовского и начали отступать в Россию. Во время сего выступления был с неприятелем в сражении: 27 и 28 июня при местечке Мир Гродненской губернии, июля 2 при местечке Романово Минской губернии, за что удостоен высочайшего благоволения, 9-го и 10-го в Белоруссии близ города Могилева, 24-го при местечке Лиды Смоленской губернии, августа 2-го при городе Красном, 3,4, 5, 6 при городе Смоленске, 7-го...» (ГАРО. Ф. 344. ОП. 1. Д. 226. Л. 7-7 об.). И так постепенно доводит до сражения «близ города Можайска на позиции при Бородине» (ГАРО. Ф. 344. Оп. 1. Д. 226. Л. 7об.)

На Бородинском поле казаки Карпова прикрывали левый фланг русской армии. Против них стоял 5-й польский корпус Понятовского, имевший задание обойти левый фланг русских и выйти в тыл Багратиону. По ряду причин, в том числе и из-за казаков Карпова, обход не состоялся (Арзамасцев).

После Бородинского сражения и оставления Москвы казаки Карпова прикрывали отход русской армии на позицию под Тарутино. «И как во все время расположения на этой позиции армии, так и в преследовании за границу командовал 10-ю казачьими полками при главной армии в авангарде у содержания передовых постов и с оными был в неоднократных с неприятелем сражениях» (ГАРО. Ф. 344. Оп. 1. Д. 226. Л. 7об.). Перечисляются бои под Малоярославцем, Боровском, Вереей, Дорогобужем, Смоленском, Красным, под многими другими селениями, и, наконец, разгром французов «при Борисове», т.е. на Березине. За Тарутино Карпов получил орден Святой Анны 1-го класса, а за события «при Борисове и как за преследование неприятеля, так и за сражения в то время бывшие», он был награжден «Георгием» 3 класса (ГАРО. Ф. 344. Оп. 1. Д. 226. Л. 8). И далее без перерывов - бои 1813 г.

Здесь образ Акима Карпова в какой-то мере противопоставлен образу Матвея Платова, олицетворявшего в армии донское казачество. После неоднозначно трактуемого рейда на Бородинском поле и неудачного командования арьергардом Платов был отстранен от командования, но после ряда скандальных заявлений получил из прибывшего с Дона ополчения под свое командование ряд полков и опять стал блистать на поле боя. После перехода границы и до августа 1813 г. он снова впал в «сокрушение» и лишь под Альтенбургом показал себя настоящим военачальником. Карпов же всегда в строю и со своими казаками участвует во всех важных событиях. Одно перечисление мест боев в 18131814 гг., написанное убористым почерком, занимает в его послужном списке две страницы. Командование казачьими полками авангарда главной армии, награждение еще раз саблей, но уже с алмазами, награждение орденом Святого Владимира 2-й степени и королевскопрусским красного орла 2 класса, производство в генерал-лейтенанты (17 января 1814 г.), вступление в Париж...

После победы М.И. Платов с императором Александром I отправился в Англию, а Аким Карпов, сдав командование многочисленными полками, во главе полка «своего имени» отбыл на Дон, куда и прибыл 1 октября 1814 г. В день прибытия он вновь стал командиром донской конной артиллерии. 
Послужной список 1816 г. констатирует, что Карпов состоит «в комплекте при артиллерии» (ГАРО. Ф. 344. Оп. 1. Д. 226. Л. 15 об.-16). Интересно, что его материальное положение резко улучшилось: у него 267 душ крепостных (ГАРО. Ф. 344. Оп. 1. Д. 226. Л. 5 об.). Меняется его «прописка». Из города Черкасска, переименованного в станицу Старочеркасскую, Аким Карпов перебирается в Новочеркасск, как и большинство служилой верхушки. Отныне он приписан к станице Средне-Новочеркасской (Корягин, 1999: 8).

С 1817 по 1821 г. Аким Карпов являлся первым предводителем донского дворянства, а в 1819 г. вошел в состав комитета по устройству Войска Донского (Безотосный, 1999: 167).

B книге «Донцы XIX века» говорится: «Будучи первым начальником донской артиллерии, он дал ей правильное устройство. Не бесполезен был он Войску и в должности войскового дворянского депутата» (Донцы, 1907: 172). Имущество А.А. Карпова продолжало разрастаться. Его сестра, Екатерина Акимовна, после смерти своего мужа, генерала Г.А. Дячкина, унаследовала имение в слободе Дячкиной, но ушла в монастырь и имение передала брату, Акиму Акимовичу (Корягин, 1999: 11).

В отставку он вышел 11 марта 1836 г. Через год, 26 марта 1837 г., Аким Акимович Карпов умер.

Он оставил многочисленное потомство. На 1816 г. в послужном списке он записал: «Женат на штаб-офицерской дочери Марфе Васильевой, имеет детей сынов 1 Екима 26, 2 Петра 24, в службе штаб-офицерами, 3 Ивана 18, 4 Афанасия 17, 5 Иосифа 16, в службе обер-офицерами, 6 Алексея 12, 7 Василия 10 лет, и дочь Анну 11 лет» (ГАРО. Ф. 344. Оп. 1. Д. 226. Л. 150б.-16).

Три его сына, два внука и даже один правнук вышли в генералы. Все они продолжали честно служить России.

\section{4. Заключение}

Перед нами образ представителя очередного поколения донской казачьей верхушки. Это дети донских старшин, ставших таковыми за успехи в службе, но вышедших из простых казачьих семей. Таковым был, например, М.И. Платов. Они роднятся через брак со старой донской верхушкой, но служат, служат и служат. Вспомним, что А.А. Карпов трижды на несколько лет посылался на Кавказ. Они старательно занимаются административной деятельностью, осваивают новый род войск. Естественно, их стереотип поведения - царская служба, а отнюдь не морские походы «за зипунами». На примере жизни А.А. Карпова мы видим, как меняются и сама донская казачья верхушка, и ее ценности.

\section{5. Благодарности}

Исследование выполнено в рамках проекта Российского научного фонда № 17-18-01411 «Войны и население юга России в XVIII - начале XXI в.: история, демография, антропология».

\section{Литература}

Арзамасцев - Арзамасцев И.В. Мемуары Людвика Ельского и его взгляд на бои на Старой Смоленской дороге и в Бородинском сражении. [Электронный ресурс]. URL: https://www.borodino.ru/wp-content/uploads/2017/o8/4_Arzamastsev_I.V.pdf (дата обращения: 01.06.2021).

Безотосный, 1999 - Безотосный В.М. Донской генералитет и атаман Платов в 1812 году. Малоизвестные и неизвестные факты на фоне знаменитых событий. М.: РОССПЭН, 1999. $192 \mathrm{c}$.

Венков, 2013 - Венков А.В. Казаки против Наполеона. От Дона до Парижа. М.: Вече, 2013. $368 \mathrm{c}$.

Венков, 2014 - Венков А.В. Атаман Войска Донского Платов. М.: Вече, 2014. 480 с.

ГАРО - Государственный архив Ростовской области.

Донцы XIX века, 1907 - Донцы XIX века: [биографии и материалы для биографий донских деятелей на поприще службы военной, гражданской и общественной, а также в области наук, искусств, литературы и пр.]. Т. 2. [Новочеркасск, 1907]. 309 с.

Донцы-кавалеры, 1911 - Донцы-кавалеры ордена Святого Великомученика и Победоносца Георгия: 1775-1908 г. М.: Типография М.Г. Сазонова, 1911. 95 с. 
Записки донского атамана, 2000 - Записки донского атамана Денисова. СПб.: ВИРД, 2000. $253 \mathrm{c}$.

Коршиков, 1999 - Коршиков Н.С. Из истории донского дворянства // Проблемы источниковедения и отечественной истории (Памяти А.П. Пронштейна). Ростов-на-Дону: Логос, 1999. С. 226-243.

Корягин, 1999 - Корягин С.В. Рубашкины и другие. Генеалогия и семейная история донского казачества. Вып. 6. М.: Пробел, 1999. 96 с.

Корягин, 2014 - Корягин C.В. Русско-турецкая война. 1806-1812 (период 1806-1809). Генеалогия и семейная история донского казачества. Вып. 113. М.: Древлехранилище, 2014. $605 \mathrm{c}$.

Потто, 1994 - Потто В.A. Кавказская война. От древнейших времен до Ермолова. Т. 1. Ставрополь: Кавказский край, 1994. 672 с.

Преснухин, 2011 - Преснухин $M$. «Бог войны» на Дону: конная артиллерия Донского казачьего войска // Родина. 2011. № 7. С. 19-21.

\section{References}

Arzamastsev - Arzamastsev, I.V. Memuary Lyudvika El'skogo i ego vzglyad na boi na Staroi Smolenskoi doroge i v Borodinskom srazhenii [Memoirs of Ludvik Yelsky and his view of the battles on the Old Smolensk Road and in the Battle of Borodino]. [Electronic resource]. URL: https://www.borodino.ru/wp-content/uploads/2017/o8/4_Arzamastsev_I.V.pdf (accessed on: June 1, 2021). [in Russian]

Bezotosnyi, 1999 - Bezotosnyi, V.M. (1999). Donskoi generalitet i ataman Platov v 1812 godu. Maloizvestnye i neizvestnye fakty na fone znamenitykh sobytii [Don generals and ataman Platov in 1812. Little-known and unknown facts against the background of famous events]. M.: ROSSPEN, 192 p. [in Russian]

Dontsy XIX veka, 1907 - Dontsy XIX veka: [biografii i materialy dlya biografii donskikh deyatelei na poprishche sluzhby voennoi, grazhdanskoi i obshchestvennoi, a takzhe v oblasti nauk, iskusstv, literatury i pr.] [Residents of the Don of the XIX century: [biographies and materials for biographies of Don figures in the field of military, civil and public service, as well as in the field of sciences, arts, literature, etc.]. Vol. 2. [Novocherkassk, 1907]. 309 p. [in Russian]

Dontsy-kavalery, 1911 - Dontsy-kavalery ordena Svyatogo Velikomuchenika i Pobedonostsa Georgiya: 1775-1908 g. [The residents of the Don - the knights of the the Order of Saint George: 1775-1908]. M.: Tipografiya M.G. Sazonova, 1911. 95 p. [in Russian]

GARO - Gosudarstvennyi arkhiv Rostovskoi oblasti [State archive of Rostov region].

Korshikov, 1999 - Korshikov, N.S. (1999). Iz istorii donskogo dvoryanstva [From the history of the Don nobility]. Problemy istochnikovedenija i otechestvennoj istorii (Pamjati A.P. Pronshtejna) [Problems of Source Studies and National History (In memory of A.P. Pronstein)]. Rostov-na-Donu: Logos, pp. 226-243. [in Russian]

Koryagin, 1999 - Koryagin, S.V. (1999). Rubashkiny i drugie. Genealogiya i semeinaya istoriya donskogo kazachestva. Vyp. 6 [Rubashkins and others. Genealogy and family history of the Don Cossacks. Issue 6]. M.: Probel, 96 p. [in Russian]

Koryagin, 2014 - Koryagin, S.V. (2014). Russko-turetskaya voina. 1806-1812 (period 18061809). Genealogiya i semeinaya istoriya donskogo kazachestva. Vyp. 113 [Russian-Turkish War. 1806-1812 (period 1806-1809). Genealogy and family history of the Don Cossacks. Issue 113]. M.: Drevlekhranilishche, 605 p. [in Russian]

Potto, 1994 - Potto, V.A. (1994). Kavkazskaya voina. Ot drevneishikh vremen do Ermolova [The Caucasian War. From ancient times to Yermolov]. Vol. 1. Stavropol': Kavkazskii krai, 672 p. [in Russian]

Presnukhin, 2011 - Presnukhin, M. (2011). «Bog voiny» na Donu: konnaya artilleriya Donskogo kazach'ego voiska ["God of War" on the Don: horse artillery of the Don Cossack Army]. Rodina. 7: 19-21. [in Russian]

Venkov, 2013 - Venkov, A.V. (2013). Kazaki protiv Napoleona. Ot Dona do Parizha [The Cossacks against Napoleon. From the Don to Paris]. M.: Veche, 368 p. [in Russian]

Venkov, 2014 - Venkov, A.V. (2014). Ataman Voiska Donskogo Platov [Ataman of the Don Army Platov]. M.: Veche, 480 p. [in Russian] 
Zapiski donskogo atamana, 2000 - Zapiski donskogo atamana Denisova [Notes of the Don ataman Denisov]. SPb.: VIRD, 2000. 253 p. [in Russian]

\section{Жизнь и служба Отечеству генерала А.А. Карпова}

Андрей Вадимович Венков а,*

а Федеральный исследовательский центр Южный научный центр Российской академии наук, Российская Федерация

Аннотация. В Ростовской области с 2013 г. затягивается решение вопроса о перезахоронении останков трех донских казачьих генералов, героев войны 1812 г. - генераллейтенанта А.А. Карпова, генерал-майора П.М. Грекова и генерал-майора Г.А. Дячкина. Их останки были обнаружены в Тарасовском районе Ростовской области учащимися и преподавателями Шахтинского Я.П. Бакланова казачьего кадетского корпуса. Во время революции 1917 г. их прежние захоронения были разрушены и разграблены. Обнаруженные тела хаотично лежали вперемешку со строительным мусором. Все еще тянется процесс идентификации обнаруженных останков. Когда он завершится, донские генералы будут преданы земле согласно их статусу и заслугам. Данная статья дает краткую биографию одного из заслуженных донских генералов, чей прах пока еще не нашел успокоения. Исследуя его жизненный путь, мы обнаружили ряд проблем, связанных со становлением новой донской казачьей элиты, которая стала формироваться в конце XVIII - начале XIX вв.

Ключевые слова: казаки, служба, казачья элита, войны, донская артиллерия.

\footnotetext{
${ }^{*}$ Корреспондирующий автор

Адреса электронной почты: andrey_venk@rambler.ru (А.В. Венков)
} 